\title{
A critical vision of the CLIL approach in secondary education: A study in the Valencian Community in Spain
}

\author{
Francisco Guillamón-Suesta ${ }^{a}$, Maria Luisa RenAu Renau ${ }^{\text {b* }}$ \\ ${ }^{a}$ Universitat Jaume I, Castellón de la Plana, Spain \\ ${ }^{\mathrm{b}}$ Universitat Jaume I, Castellón de la Plana, Spain \\ *Corresponding author: renau@uji.es
}

\section{ABSTRACT}

This paper presents a research study into CLIL in secondary education in the area of Castellón in the Valencian Community, Spain. Our first objective of this work involves defining whether some content subjects in some secondary schools of the area are being delivered using English as the vehicular language or not. Secondly, the study also pursues to detect the attitudes and background of the English and the content teachers of those centres in relation to CLIL by means of two types of CLIL questionnaires. Results show that even though CLIL has not been introduced officially in any of these secondary schools, some of the teachers have already applied it in specific modules of nursery and primary education. English and content teachers show a positive attitude towards the effects that CLIL could have on their students, and they are eager to cooperate in its implementation.

Keywords:

CLIL; Spanish and Valencian CLIL contexts; CLIL in secondary education; English and content teachers.

\author{
RESUMEN
}

Este trabajo presenta un estudio de investigación sobre el enfoque AICLE en la educación secundaria en el área de Castellón en la Comunidad Valenciana, España. Nuestro primer objetivo consiste en definir si algunas asignaturas de contenido en algunas escuelas secundarias de la zona están utilizando el inglés como lengua vehicular o no. En segundo lugar, el estudio también persigue detectar las actitudes y los antecedentes tanto de los profesores de Inglés y como de los de contenido de esos centros en relación con el enfoque AICLE, por medio de dos tipos de cuestionarios. Los resultados muestran que, a pesar de que AICLE no ha sido introducido oficialmente en estos centros de enseñanza secundaria, algunos de los profesores ya lo han aplicado en algunos módulos específicos de educación infantil y primaria. Tanto los profesores de Inglés y como los profesores de asignaturas de contenido muestran una actitud positiva hacia los efectos que podría tener el enfoque AICLE sobre sus alumnos, y están dispuestos a cooperar en su implementación.

\section{Palabras Claves:}

AICLE, contextos AICLE en español y en valenciano, AICLE en la educación secundaria, profesores de asignaturas de inglés y profesores de asignaturas de contenido.

\section{INTRODUCTION}

During the last few decades, European countries have experienced an increasing tendency to implement methodologies within their education systems that are based on bilingual or multilingual programmes. The main purpose of this policy is to promote and accelerate the acquisition of a complete linguistic competence in a foreign language through a permanent and constant contact with the language, which is no longer restricted to the traditional linguistic module (Lorenzo, Casal, \& Moore, 2009).

One of the most widespread multilingual approaches that focuses on the premises is the Content and Language Integrated Learning (henceforth, CLIL). According to Coyle, Hood, and Marsh (2010, p. 1), CLIL can be defined as 'a dual-focused educational approach in which an additional language is used for the learning and teaching of both content and language'.

Therefore, this methodological approach offers the students not only the possibility of learning the contents of a specific module, such as History or Science, but also an evident improvement of language skills with an additional language, according to Ioannou-Georgiou and Pavlou (2011). What makes CLIL characteristic from other multilingual education approaches lies in the fact that the vehicular language corresponds to a foreign language, which is not common in the students' usual environment, Dalton-Puffer, Nikula, and Smit (2010).

It is important to point out that CLIL lessons do not aim to teach content concepts from a foreign language subject perspective. Thus, the target language also remains as an independent module in the curriculum that covers the traditional linguistic features, that is, grammar, vocabulary or communicative skills, among others as Wolff (2007) affirms. 
Moreover, the recent character of the CLIL approach in educational institutions has considerably limited the number of methodological and pedagogic resources available to teachers Meyer (2010). Because of that, Coyle (2006) proposes the 4Cs Framework, which includes a combination of the necessary theoretical principles in order to plan CLIL lessons from a cohesive and integrative point of view. In particular, the 4Cs conventions are the following:

a. Content: it refers to the individual acquisition of knowledge, understanding and development of the skills of a specific content subject that students are supposed to perform.

b. Cognition: it is connected to the thinking processes that enable both concept learning and linguistic demands simultaneously.

c. Communication: it is used to learn and reconstruct the input given as well as to interact in the foreign language within the learning context.

d. Culture: it is essential in CLIL because it makes students aware of the relationship between languages, cultures, history and themselves.

Navés (2009) establishes a set of parameters and conditions that should be followed so as to develop adequate CLIL policies. Firstly, the learners' culture and L1 need to be respected, since they represent a significant influence in the foreign language learning. Secondly, teachers in charge of the CLIL instruction are required to be bilingual or multilingual and completely trained, and it is convenient that they hold a stable position within the educational institution. Thirdly, the target language should be integrated and contextualised within the classroom. Additionally, students' parents need not only to be implicated and support the CLIL implementation, but also to collaborate with teachers. Finally, assessment and materials utilised when dealing with CLIL contexts have to be planned carefully.

Another decisive aspect to be taken into account when implementing CLIL programmes successfully lies in the fact that teachers are required to be teachers of both language and content simultaneously (Cummins, 1994). Since this condition is hardly viable, Jacobs (2005) claims that team teaching is the more appropriate methodology to be adopted.

Team teaching can be defined as a collaborative and 'pedagogical method in which teachers of the same or of different subject areas co-operate in the planning, realisation and further development of an educational course, programme, etc.' (Kaseva \& Schwartz, 2006, p. 6). Hence, it involves mutual support and learning from and with each other, especially from the language teacher towards the content teacher, in the form of development of content terminology and materials, and advising on how the linguistic issues should be assessed (Pavón-Vazquez \& Ellison, 2013). This is an extremely usual situation that occurs when imparting CLIL lessons, since content teachers are neither native speakers nor experts in the foreign language, so they do not feel totally adapted and comfortable communicating in that language (Dalton-Puffer et al., 2010).

Nevertheless, teacher training is required, since traditional methodologies employed by teachers need to be modified and adapted to the innovative CLIL conditions and competences, as Pavón-Vazquez \& Ellison (2013) point out. Linguistics such as Dalton-Puffer et al. (2010) have speculated about the possibility that specific didactics adapted to the CLIL classroom necessities might be developed in the future. In the meantime, CLIL is represented as an umbrella term that embodies all educational levels and provides a modular and flexible methodology that can be adapted in consonance with the needs of a particular educational setting, in terms of duration and intensity (Coyle 2006; Mehisto, Marsh, \& Frigols, 2008). Regarding the benefits of CLIL instruction, it seems evident that the overall linguistic competences in the foreign language are favoured in comparison with traditional language lessons. Besides, CLIL improves lexicon knowledge, oral and written proficiency (IoannouGeorgiou 2012), learners' motivation and attention (Lasagabaster, 2011), and reading comprehension (Admiraal, Gerard, \& de Bot, 2006).

\section{Historical Background}

Historically, the term content and language integrated learning (CLIL) was conceived in 1994 in the European area as an attempt to enclose all the dual experiences consisting in teaching and learning content through a foreign language that were taking place at the time. Bearing that idea in mind, one of the main objectives of the creation of the notion of CLIL was to design and plan recommended guidelines that could be followed by administrations

Guillamón-Suesta, F., \& Renau Renau, M. L. (2015). A critical vision of the CLIL approach in secondary education: A study in the Valencian Community in Spain. Latin American Journal of Content and Language Integrated Learning, 8(1), 1-12. doi:10.5294/laclil.2014.8.1.1 eISSN 2322-9721. 
or educational institutions that were willing to implement this specific methodological approach (Marsh, Maljers , \& Hartiala, 2001).

Nevertheless, the interest in teaching foreign languages has ancient origins, as Coyle et al. (2010, p. 2) illustrate 'education in a language which is not the first language of the language of the learner is as old as education itself'. The first evidences of this premise is early exemplified in the Roman Empire more than two thousand years ago. In a period of enlargement and growth, Romans annexed considerable Greek territory and the tendency of learning Greek expanded throughout Roman families, as a method of improving their social and professional possibilities in Greek areas. These first manifestations can be adopted to establish a parallelism with the current status of English, which aims to evolve into a universal lingua franca in a globalised world that is administrated by social and economic forces.

\section{CLIL in Europe}

The European Union is promoting actively the learning of foreign languages and the linguistic diversity in education so as to facilitate professional opportunities and mobility among countries, and to improve mutual understanding. Besides, there are other reasons that support multilingual proficiency, since it also benefits individuals' cognitive abilities and strengthens their L1 commands (European Commission, 2008).

Consequently, the characteristics of the European Union lead it to adopt a multilingual policy that ensures its unity and diversity principles, which are derived from the large variety among its members. Particularly, it currently comprises 4 million $\mathrm{km} 2$ and 503 million inhabitants in total, which are distributed in 28 countries and speak 24 different official languages; a number that increases when adding other minority and regional languages (European Union, 2014). As a result, two institutions, the European Commission and the Council of Europe, are responsible for planning and applying education policies that guarantee this linguistic diversity (Dalton-Puffer $e t$ al., 2010).

One of the first regulations concerning CLIL was passed in the European Union in the 1995 Resolution of the Council, which aimed to establish innovative methods within education and drive bilingual policies by teaching content areas in a foreign language rather than restricting it to the traditional linguistic subject. Also, the Council suggested improving the quality of foreign languages teachers via exchange stays in other European states (European Commission 1995). Those ideas were corroborated again in 2002 in the Barcelona European Council, which appealed for teaching in at least two foreign languages from early stages (Eurydice 2006). Following that symposium, the Commission launched in 2003 its Action Plan for the period 2004-2006 with the premise of introducing learning of both content and language through CLIL, which was described as having 'a major contribution to make to the Union's language learning goals' (European Commission Communication 2003, p. 8). Thus, CLIL is listed as one of the most prominent activities within the Council of Europe's language policy unit, that is to say, the European Centre for Modern Languages (Dalton-Puffer et al., 2010).

Other CLIL oriented activities funded by the European Union include the mobility programmes Socrates, Comenius and Erasmus that cover the spectrum of the different educational levels and deal with the design and application of curricula and multidisciplinary activities focused on teaching in foreign languages. Furthermore, the European Union also works towards constant innovation in the education research field (both teaching and learning) in projects such as the European Label for Innovation or the European EuroCLIC network (Eurydice 2006).

\section{CLIL in Spain}

Spain has become one of the leaders in both CLIL implementation and practice with mainly English as the target language, due to the linguistic diversity found in the country and the awareness of the importance that learning foreign languages have in a globalised society (Coyle 2010). Before analysing the relevance of the CLIL methodological approach within this country, it is necessary to remind that, at the present time, the national education law, approved in 2006, defines the foundations of the different regional education systems (Lasagabaster \& Ruiz de Zarobe 2010). Focusing on CLIL, one of the premises is to support multilingualism and enhance the learning of two foreign languages, in other words, to follow European Union's recommendations and guidelines (Ministerio de Educación, Cultura y Deporte, 2013). Nonetheless, each autonomous community can regulate and

Guillamón-Suesta, F., \& Renau Renau, M. L. (2015). A critical vision of the CLIL approach in secondary education: A study in the Valencian Community in Spain. Latin American Journal of Content and Language Integrated Learning, 8(1), 1-12. doi:10.5294/laclil.2014.8.1.1 eISSN 2322-9721. 
design its own particular educational system based on its needs and interests, on the condition that it follows the requirements established in the legal framework marked by the state educational law (Lasagabaster \& Ruiz de Zarobe 2010).

One of the earliest initiatives to introduce CLIL in Spain was promoted in 1996 by the Spanish Ministry of Education and Science together with the British Council, who agreed to create the Bilingual and Bicultural Project, based on an integrated English and Spanish curriculum, and established it in 43 state schools (Coba Arango 2010). This pilot experience represented the starting point for independent CLIL programmes in the different Spanish autonomous communities. Catalonia can be considered as one of the pioneer regions to apply CLIL in public schools throughout the Orator Project and the Foreign Language Experimental Plan, which were valid from 1999 to 2008 and resulted in a steady increment in the CLIL figures until reaching 77 primary schools and 58 secondary schools in the academic year 2008-9 (Navés \& Victori, 2010). Moving to another bilingual community, Galicia, it should be indicated that its first pilot CLIL experiences in secondary school began in 1999, which motivated the approval of specific legislation concerning CLIL instructions, such as the Languages Plan (San Isidro 2010a). Consequently, the number of primary and secondary schools involved in this pedagogical approach has increased up to more than 200 (San Isidro 2010b).

The Basque Country has also made notable efforts in order to combine English, Basque and Spanish in schools and improve the communicative competence of students in foreign languages. As Lasagabaster and Ruiz de Zarobe (2010) declare, the legislative actions approved by the Basque government to encourage multilingualism towards CLIL can be summarised into the following projects: Early Start to English, INEBI (English through Content in Primary Education), BHINEBI (English through Content in Secondary Education) and the Plurilingual Experience for Secondary Education and Bachillerato. The region of Navarre, which is located next to the Basque Country and presents some Basque-speaking areas, has also carried out some CLIL pilot projects (Navés \& Muñoz, 1999). What is more, the Balearic Islands firstly mentioned the possibility of teaching parts of the curriculum in primary and secondary public schools in a foreign language in 2002 (Conselleria d'Educació i Cultura 2002a; $2002 b)$. After that, new regulations were passed until the Order of 2009, the aim of which was to unify previous legislations regarding the CLIL approach and promote a widespread implementation of CLIL programmes (named European Sections in the Islands) in all stages of public education (Pérez-Vidal \& Juan-Garau 2010).

The Valencian Community presents a bilingual background in which both Spanish and Catalan, or Valencian, co-exist with official linguistic status, even though Spanish has more social influence in some specific areas, such as the inner zone in the province of Valencia or the further south in Alicante. With that, $78.2 \%$ of the population is perfectly able to understand the regional language without major problems, as reported in a recent sociolinguistic survey (Pons \& Sorolla 2009).

\section{Objectives}

Bearing in mind the ideas presented in the previous sections, the aim of this paper is to critically analyse the CLIL situation and relevance in a specific part of Spain, the province of Castellón in the Valencian Community, and determine whether its secondary schools (2 public and 2 Catholic state-funded) have implemented the CLIL methodological approach within their education and linguistic projects. What is more, an additional objective of the research is to objectively examine and reflect the English and content teachers' impressions and beliefs towards CLIL and the viability of its possible future application.

\section{METHOD}

The purpose of this research consists in the analysis of the CLIL situation in secondary education in the Alcalatén region in Castellón (Spain) and the evaluation of its teachers' opinions about this methodological approach. Before presenting the method used to undertake this study, it should be explained that the Alcalaten region is the name given to a territory formed by the villages of l'Alcora, Adzeneta del Maestrat, Benafigos, Costur, Chodos, Figueroles, Lucena del Cid, Les Useres and Vistabella del Maestrazgo. In spite of that, secondary education is only offered in l'Alcora by the state institutions IES Ximén d'Urrea and IES L'Alcalatén, and the state-funded Catholic institutions Colegio Puértolas Pardo and Colegio La Salle.

Guillamón-Suesta, F., \& Renau Renau, M. L. (2015). A critical vision of the CLIL approach in secondary education: A study in the Valencian Community in Spain. Latin American Journal of Content and Language Integrated Learning, 8(1), 1-12. doi:10.5294/laclil.2014.8.1.1 elSSN 2322-9721. 
Therefore, in order to achieve the aims of the research, two different questionnaires were designed and distributed among English and content teachers from those four secondary schools. Once the questionnaires were completed and collected from the centres, all the data derived from them was subsequently classified so as to facilitate its later analysis and the results interpretation.

\section{Participants}

\section{Ximén d'Urrea Secondary School}

The IES Ximén d'Urrea is located in Castellón Avenue, 33 in l'Alcora and, apart from taking students who are born in l'Alcora (Castellón, Spain), is also the reference centre for students coming from the surrounding villages. Its education programmes include the entire secondary education stages, being the only one in the region that offers Bachillerato, and Vocational Training Certifications (two intermediate and one higher grades).

From this state secondary school, 12 teachers participated in the study (5 men and 7 women): 4 English teachers, 2 Biology teachers, 2 Technology teachers, 1 Maths teacher, 1 History teacher, 1 Physics teacher and Chemistry teacher, and 1 Computer Science teacher.

\section{L'Alcalatén Secondary School}

The second state secondary school in l'Alcalatén is named after the region and is situated in C/Músic Pere Moliner, 2 in l'Alcora (Castellón, Spain). It offers the four compulsory secondary courses.

From this state secondary school, ten teachers (seven men and three women) were involved in the research: 3 English teachers, 1 Gardening teaching, 1 Physics and Chemistry teacher, 2 Technology teachers, 2 History teachers and 1 Biology teacher.

\section{Puértolas Pardo School}

This is a religious Catholic school that is partially funded by the government and is placed in Glorieta Santa María Rosa Molas, 1 in l'Alcora (Castellón, Spain). It covers all the educational levels except for Bachillerato and one of its projects for next year is the adhesion of nursery to the Xarxa de Centres Docents Plurilingües de la Comunitat Valenciana (Conselleria d'Educació, Formació i Ocupació 2014).

From this school, 6 teachers took part in the study ( 2 men and 4 women), particularly: 1 English teacher, 1 Maths teacher, 1 Science teacher, 2 History teachers and 1 Art teacher.

\section{La Salle School}

The Colegio La Salle is located in 1, La Salle Square in l'Alcora (Castellón, Spain) and it is also a religious Catholic school that receives funding from the government.

From this school, 7 teachers ( 2 men and 5 women) were participants in the research and were categorised into 1 English teacher, 2 Maths teachers, 1 Music teacher, 1 Science teacher, 1 Physical Education teacher and 1 History teacher.

\section{Materials}

The participants of the study were required to fill in a specific questionnaire according to their speciality. Because of that, two different models of the questionnaire were created: one for English teachers and one for content teachers. Both of them were translated into Catalan, since most of the teachers interviewed did not have sufficient English knowledge. Besides, it is necessary to remark that some of the questions were adapted from Sancho Guinda (2013).

\section{Questionnaire for English Teachers}

The questionnaire for English teachers included thirteen questions, which were divided into two sections: A) Personal Information and B) CLIL Questionnaire. At first, the personal section comprised three questions regarding the gender, the number of years in teaching and the centre of the teacher, whereas the second part was constituted by ten questions, five of them were yes or no, two were multiple choice and the rest were short answer questions. The CLIL questionnaire began by asking the teachers if they knew what the CLIL 
methodological approach was, and also provided a short definition of it in case that the answer was negative. After that, the aim of the second and third questions were to define if any CLIL programmes were implemented in the school, in which levels and if the teacher had collaborated in the process. Next in order, the fourth and fifth questions dealt with the English linguistic competence of students and their level based on the Common European Framework of Reference for Languages. Then, the sixth question made the teachers think about whether a CLIL approach would improve the English level of students. The seventh question was designed as a multiple choice, so teachers were able to circle the options that best expressed the difficulties that content teachers would face in a CLIL environment. Following that, the eighth question concerned the English teachers' willingness to co-operate in the elaboration of CLIL materials. Lastly, the ninth and tenth questions were planned to reflect the advantages and disadvantages that the CLIL methodological approach has in the English teacher's view.

\section{Questionnaire for Content Teachers}

The questionnaire for content teachers was structured in sixteen questions and divided as well into a) Personal Information and b) CLIL Questionnaire. The first part was similar to the questionnaire for English teachers, but in this case the teacher's speciality was also required in an additional question; whilst the second part was integrated by six yes or no questions, two multiple choice and four short answer questions. Dealing with the CLIL questionnaire itself, the first, second and third questions were identical to the ones in the questionnaire for English teachers. Later, the teacher's capacity of using English as the target language was asked. Next, the fifth and sixth questions were connected to the students' level of English, as the fourth and fifth questions of the questionnaire for English teachers. After that, the seventh question tried to determine if teachers would decrease their class rhythm and which would be the reasons. The following question was the multiple choice one that corresponds to question seven in the other questionnaires. The ninth and tenth questions aimed to detect if it seemed to the teachers that they could impart content through English. Finally, the last two questions focused on the advantages and disadvantages that a CLIL methodological approach presents in their particular content subject.

\section{RESULTS}

This section of the paper contains the results derived from the questionnaires filled in by both English and content teachers. In order to structure those results, it is crucial to highlight that the questionnaires for each type of teacher (English or content teachers) will be assessed separately, without creating school distinctions or considering personal information.

\section{English Teachers}

On the one hand, the questionnaire for English teachers was undertaken by a total of 19 individuals. Beginning with the first question, $77.8 \%$ of them presented CLIL notions, while a percentage of $22.2 \%$ did not show knowledge on the CLIL methodology.

From the total amount of English teachers, only two affirmed that their institutions were offering CLIL programmes, which were the Colegio Puértolas Pardo and the Colegio La Salle. Specifically, the subjects instructed in English correspond to Psychomotricity in nursery in the former, and Arts and Crafts in primary education in the latest. In both cases, the English teachers of the schools were involved in their correct implementation.

Following that, concerned the suitable linguistic preparation of students so as to success in a subject with CLIL. 33.3\% of the teachers answered affirmatively and 66.7\% negatively, with the argument that CLIL should be applied progressively. Apart from that, English teachers were asked to point out the language level of their students in particular according to the Common European Framework of Reference for Languages, and all of them agreed that it ranged from A1 to B1, depending on the course. Then, English teachers believe that CLIL is potentially beneficial for increasing the students' communicative competence; a statement that $88.9 \%$ of the survey respondents agreed with. In spite of that, $11.1 \%$ of the teachers defended that it depended on how properly the subject was developed.

As far as teachers' capacities are concerned, most of the participants indicated that the main teaching difficulties CLIL seems to entail include i) the specific vocabulary of the subject and the expressions required for

Guillamón-Suesta, F., \& Renau Renau, M. L. (2015). A critical vision of the CLIL approach in secondary education: A study in the Valencian Community in Spain. Latin American Journal of Content and Language Integrated Learning, 8(1), 1-12. doi:10.5294/laclil.2014.8.1.1 elSSN 2322-9721. 
the class interaction, ii) the structures and terms needed to explain, summarise and solve doubts, the low level of students in English and iii) the elaboration of customised materials and the implementation of appropriate teaching methodologies.

Furthermore, $55.6 \%$ of the English teachers interviewed would be willing to collaborate in the creation of educational materials with CLIL and $44.4 \%$ of them, which increases up to $100 \%$ in the IES L'Alcalatén, would be reticent.

About the advantages and disadvantages of CLIL, 67\% of the English teachers were not able to identify any disadvantages. This is summary of the main advantages and disadvantages they contemplate when CLIL approach is going to be implemented:

\section{- Advantages}

- General improvement in the level of English of the students.

- Possibility of oral interaction and development of listening comprehension.

- Expansion in vocabulary.

\section{- Disadvantages}

- Excessive focus on the linguistic components, to the detriment of the content side.

- Lack of awareness of the technical terms in the students' own language.

$\circ \quad$ No acquisition of contents in students with low level of English.

\section{Content Teachers}

The questionnaire for content teachers was completed by a total of 46 participants. $42.3 \%$ of the individuals expressed that they had the CLIL concept clear, whereas the $57.7 \%$ did not have notions of that methodological approach.

The Colegio La Salle offers CLIL in Arts and Crafts in primary schools and that the Colegio Puértolas Pardo has established CLIL in Psychomotricity in nursery. At this point, it has to be specified that only 2 out of the 5 teachers from the Colegio Puértolas Pardo were conscious that they had introduced the CLIL approach in their curriculum. The results showed that none of the teachers interviewed from Colegio Puértolas Pardo and only 30\% of the teachers from the Colegio La Salle participated actively in the introduction of CLIL in their centres.

$92.3 \%$ of the participants argued that they were not sufficiently confident or prepared to perform a class in the foreign language, even though $30 \%$ of them presented a B2 level. On the contrary, 7.7\% of the teachers considered that they were capable of implanting CLIL with their B2 certificates in English. Moving to students' proficiency, $100 \%$ of the interviewees agreed that in the present time students are not prepared to face a CLIL context, although if CLIL were implemented from earlier stages, students would be adapted to it when they reached secondary education.

In relation to the level of students in English according to the Common European Framework of Reference for Languages, content teachers agreed to place their students between A1 and B1, dependent upon their course.

$80 \%$ of the content teachers affirmed that they would slow down their habitual class rhythm if teaching through CLIL approach given the following reasons:

- Difficulties in the specific vocabulary.

- No proficiency in English of both students and teachers.

- Teachers are not methodologically prepared to teach in English.

- Additional linguistic difficulties to the usual content difficulties.

The majority of the teachers interviewed concurred that the main obstacles would be originated from i) the technical vocabulary of the content module, ii) the expressions to interact with the students, iii) the typical structures and vocabulary belonging to written English that are necessary to use the virtual classroom, participate in forums and answer emails, iv) the expressions employed to explain, summarise and solve doubts, v) the standard English pronunciation and, lastly, vi) the low level of students English.

Furthermore, $19.2 \%$ of the individuals confirmed that they would be predisposed to adopt a CLIL methodology, whilst most of them, $80.8 \%$, would not. Nonetheless, some of the latest expressed that they could modify their answers in the future, once they would have been trained properly. Secondly, the majority of the 
content teachers, a 73\% of them expressed that they would collaborate with the English Department in case the CLIL approach was implemented in their areas. However, a $27 \%$ of them would be reticent and claimed for more implication from the government and an improvement in the linguistic policies.

Eventually, both the advantages and disadvantages of the CLIL approach for content teachers' views if it was implemented into their subjects were asked and analysed the results. $85 \%$ did find many advantages while the remaining detected some disadvantages.

- Advantages:

- Possibility of speaking in another language.

- General improvement in the level of English.

$\circ$ Access to resources in the foreign language.

$\circ$ Improvement in the fluency, expressions and vocabulary.

- It provides a linguistic basis to travel abroad.

- Disadvantages:

- Low proficiency in English of both students and teachers that would difficult the class.

- Absence of adapted materials.

- Lack of awareness of the technical terms in the students' own language.

- No acquisition of contents.

$\circ$ Insecurity and deceleration of the rhythm of the course.

\section{DISCUSSION}

At first, it is convenient to note on the difference in CLIL knowledge between English and content teachers. While a $77.8 \%$ of the former were able to identify the meaning of CLIL, only $42.3 \%$ of the later could. This fact might be seen as a consequence of the linguistic orientation of the CLIL methodological approach, since it is prevalent a research topic in applied linguistics.

As formerly commented, Spain and, within it, the Valencia Community, can be deemed as one of the European countries where the highest amount of CLIL initiatives have recently emerged (Eurydice 2006). In relation to that, the present study revealed that two out of the four schools examined have introduced CLIL in some of their nursery or primary education subjects with the English teachers counselling, which appears to be decisive in the correct CLIL implementation (Pavón-Vazquez \& Ellison 2013). Therefore, focusing on one of the aims of the research, that is, determine whether CLIL is offered in secondary education in l'Alcalatén region, it can be asserted that none of the schools have followed that path, even though it could be introduced in the future through a progressive implementation. Nevertheless, despite forming part of the centre curriculum, it is interesting to underline that only two out of the five content teachers interviewed from the Colegio Puértolas Pardo were aware that the centre offered a subject through CLIL. That could be an after effect derived from a not well-planned organisation among the different departments of the centre.

Examining the participants' competence in English, the majority of content teachers affirmed that they did not possess the necessary linguistic confidence so as to face a CLIL subject. Also, the 66.7\% of English teachers and the $100 \%$ of content teachers agreed on the evidence that students are not currently prepared to succeed in a CLIL environment. This was probably an expected result, which was clearly diagnosed by Ioannou-Georgious (2012) as one of the main drawbacks of implementing CLIL in schools. Students from the institutions examined tend to present a level of English that varies from A1 to B1. Consequently, classrooms ranging between A2 and B1 would be the most suitable ones for introducing CLIL. However, that recognised absence of English proficiency in students may not be seen as a determinant condition not to endeavour to develop CLIL, since the low English proficiency is relatively standardised within the Spanish schools, including those where CLIL has been established. What appears to be clear is that CLIL is a methodological approach that fosters English language learning and communicate competences, which was indicated by $88.9 \%$ of English teachers coincided in stating and corresponds to one of its main objectives, as argued by Lorenzo et al. (2009).

Even with that, results suggested that content teachers would have to overcome several difficulties in order to conduct their lessons through a proper CLIL methodology. In particular, all the participants from content areas expressed that they would reduce the rhythm of the CLIL class due to i) the general low aptitude in English of 
both students and teachers, ii) the specificity of vocabulary, iii) linguistic difficulties that would combine with the usual content difficulties, and iv) the absence of methodology preparation.

In general terms, English and content teachers concurred that obstacles would be related to the content and interaction vocabulary, and the expressions required to explain, summarise and solve doubts. Apart from that, content teachers also made reference to difficulties resulting from the low level of students and when writing English, whereas its English counterparts emphasised the complication of creating specific materials adapted to CLIL. Referring to that, it has to be said that the $55.6 \%$ of English teachers would be willing to collaborate with content teachers and develop CLIL materials. On the contrary, there was a higher proclivity of content teachers, a $73 \%$, which would cooperate with English teachers, even though only a $19.2 \%$ of them believed that CLIL could be implemented in their subjects. Both teachers' predisposition towards working on CLIL materials together with colleagues from other departments can certainly be regarded as a positive fact, considering that team teaching is indispensable when adopted a CLIL methodological approach (Jacobs 2005).

Bearing in mind the results discussed above, the participants in the research attempted to compile the advantages and disadvantages of CLIL in the last part of the research throughout two different ways: English teachers took into account their personal opinion and content teachers analysed the benefits and weaknesses that CLIL would have in their particular subject. As expected, the resulting outcome was similar to the findings of Ionnaou-Georgiou (2012), Lasagabaster (2011) and Admiraal et al. (2006). Specifically, the advantages stated by both types of teachers include improvement in the level of English, possible development of oral skills, and expansion of vocabulary. English teachers also signalled the access to resources in English and the possibility of using the linguistic components acquired through CLIL when travelling abroad. In contrast, disadvantages of CLIL according to the English and content teachers interviewed encompass excessive focus only on the linguistic side of the subject, no awareness of the technical terms in the students' own language and no acquisition of contents in students with a low level of English. Lastly, content teachers emphasised the absence of CLIL materials, and the insecurity and deceleration of the rhythm of the subject caused by their poor English knowledge.

Taken into consideration the negative aspects of CLIL discussed in the previous paragraphs, it is fundamental to emphasise that some of them could be partially solved if improved English training was offered to content teachers and the English curriculum was reinforced from early stages of education, so students would be linguistically capable to face CLIL lessons.

\section{CONCLUSION}

CLIL is an innovative methodological approach that aims to foster the integrated learning of languages and other curricular contents. The multilingual condition of Europe and its members together with the current tendency of globalisation and mobility have originated an increasing development of CLIL in many countries. Besides, it has been proved that CLIL benefits and bolsters learners' foreign language skills as well as motivation and attention. Nonetheless, the correct implementation of CLIL implies reinforcement in areas such as teacher training, team teaching, education and assessment planning, and additional resources.

All this considered, the purpose of the present paper was twofold. On the one hand, it aimed to determine whether CLIL was undertaken in the four secondary schools of the Alcalatén region. On the other hand, it concentrated on the English and content teachers' background and attitudes towards the CLIL methodological approach and its possible future implementation in their centres. Regarding the first issue, it can be concluded that none of the centres analysed has introduced CLIL in secondary education, although the Colegio Puértolas Pardo offers it in nursery and Colegio La Salle has established it in primary education. Hence, CLIL might be transferred to secondary education in these Catholic funded schools in the near future throughout a progressive implementation. Dealing with the second objective of the study, the most significant findings demonstrated that the majority of English and content teachers agreed with the fact that CLIL would be positive for the students' foreign language skills and asserted that they would be willing to collaborate among them. Still, in their views, there are determining aspects to overcome before the application of CLIL as, for instance, the poor linguistic capacity of both teachers and students, the absence of adapted materials and assessment, or the government involvement. 
It is necessary to stress that the objectives of the paper only affected a specific region of Castellón (Spain). Thus, further research could be carried out by exploring other geographic areas or comparing the differences in beliefs between CLIL teachers and non-CLIL teachers. Also, a wider analysis embracing other education levels would provide a more complete insight in relation to the current CLIL trends in Spain or the Valencian Community.

\section{REFERENCES}

Admiraal, W., Gerard, W., \& de Bot, K. (2006). Evaluation of bilingual secondary education in the Netherlands: Students' language proficiency. English Educational Research and Evaluation, 12(1), 75-93.

Coba Arango, E. (2010). Foreword. In A. Dobson, M. D. Pérez Murillo, \& R. Johnstone (eds.), Bilingual education project Spain: Evaluation report 5. Madrid, Spain: Ministerio de Educación, Subdirección General de Documentación y Publicaciones.

Consejería de Educación, Ciencia y Cultura. (2011). Resolución de 07/06/2011. Diario Oficial de Castilla-La Mancha 113, 22504-9.

Consejería de Educación. (2006). Orden Edu/6/2006 de 4 de enero. Boletín Oficial de Castilla y León 8, 781-3.

Conselleria d'Educació i Cultura. (2002a). Decret 119/2002 de 27 setembre. Butlletí Oficial de les Illes Balears 120, 17281-95.

Conselleria d'Educació i Cultura. (2002b). Decret 120/2002 de 27 setembre. Butlletí Oficial de les Illes Balears 120, 17295-313.

Conselleria d'Educació. (2009). Ordre de 19 de maig. Diari Oficial de la Generalitat Valenciana 6034, 23872-6.

Coyle, D., Hood, P., \& Marsh, D. (2010). CLIL: Content and language integrated learning. Cambridge, UK: Cambridge University Press.

Coyle, D. (2006). Content and language integrated learning - motivating learners and teachers. The Scottish Language Review, 13, 1-18.

Coyle, D. (2010). Foreword. In D. Lasagabaster \& Y. Ruiz de Zarobe (eds.), CLIL in Spain: Implementation, results and teacher training (pp. vii-viii). Newcastle upon Tyne, UK: Cambridge Scholars Press.

Cummins, J. (1994). Knowledge, power and identity in teaching English as a second language. In Fred Genesse (ed.), Educating second language children: The whole child, the whole curriculum, the whole community (pp. 3358). Cambridge, UK: Cambridge University Press.

Dalton-Puffer, C., Nikula, T., \& Smit, U. (2010). Charting policies, premises and research on content and language integrated learning. In C. Dalton-Puffer, T. Nikula, \& U. Smit (Eds.), Language use and language learning in CLIL classrooms (pp. 1-20). Amsterdam, the Netherlands: John Benjamins Publishing.

Commission of the European Communities. (2003). Promoting language learning and linguistic diversity: An action plan 2004-2006. Brussels, Belgium: European Commission. Retrieved from http://eur-lex.europa.eu/legalcontent/EN/TXT/?uri=CELEX:52003DC0449

European Commission. (1995). White paper on education and learning: Teaching and learning, Towards the learning society. Brussels, Belgium: European Commission. Retrieved from http://europa.eu/ documents/comm/white_papers/pdf/com95_590_en.pdf

European Commission. (2008). Language and Europe: Language learning. http://europa.eu/languages/en/chapter/14 (10 April 2014).

European Union. (2014). EU administration - staff, languages and location. Retrieved from http://europa.eu/abouteu/facts-figures/administration/index_en.htm

Eurydice. (2006). Content and language integrated learning (CLIL) at school in Europe. Brussels: Eurydice European Unit. Retrieved from http://www.indire.it/lucabas/lkmw_file/eurydice/CLIL_EN.pdf

Fernández Fontecha, A. (2010). First steps of CLIL in a Spanish monolingual community: The case of La Rioja. In D. Lasagabaster \& Y. Ruiz de Zarobe (Eds.), CLIL in Spain: Implementation, results and teacher training (pp. 7994). Newcastle upon Tyne, UK: Cambridge Scholars Press.

Frigols, M. J., \& Michel, M. (2009). La experiencia CLIL/AICLE en el IFPS Cheste. In M. F. Ruiz Garrido \& A. M. Saorín Iborra (Eds.), Hacia una educación plurilingüe: Experiencias docentes AICLE (pp. 79-96). Castellón, Spain: Publicacions de la Universitat Jaume I.

Guillamón-Suesta, F., \& Renau Renau, M. L. (2015). A critical vision of the CLIL approach in secondary education: A study in the Valencian Community in Spain. Latin American Journal of Content and Language Integrated Learning, 8(1), 1-12. doi:10.5294/laclil.2014.8.1.1 elSSN 2322-9721. 
Ioannou-Georgiou, S., \& Pavlou, P. (Eds.). (2011). Guidelines for CLIL implementation in primary and pre-primary education. Nicosia, Cyprus: Cyprus Pedagogical Institute.

Ioannou-Georgiou, S. (2012). Reviewing the puzzle of CLIL. English Language Teaching Fournal, 66(4), 495-504.

Jacobs, C. (2005). On being an insider on the outside: New spaces for integrating academic literacies. Teaching in Higher Education, 10(4), 475-87.

Kaseva, P., \& Schwartz, K. (Eds.). (2006). Team teaching CLIL-Axis: Content and language integrated learning. Helsinki: Edita Prima Oy.

Lasagabaster, D. \& Ruiz de Zarobe, Y. (2010). CLIL in a Bilingual Community: The Basque autonomous community. In D. Lasagabaster \& Y. Ruiz de Zarobe (eds.), CLIL in Spain: Implementation, results and teacher training (pp. 12-29). Newcastle upon Tyne, UK: Cambridge Scholars Press.

Lasagabaster, D. (2011). English achievement and student motivation in CLIL and EFL settings. Innovation in Language Learning and Teaching, 5(1), 3-18.

Lorenzo, F., Casal, S., \& Moore, P. (2010). The effects of content and language integrated learning in European education: Key findings from the Andalusian sections evaluation project. Applied Linguistics, 31, 418-42.

Lorenzo, F. (2010). CLIL in Andalusia. In D. Lasagabaster \& Y. Ruiz de Zarobe (eds.), CLIL in Spain: Implementation, results and teacher training (pp. 2-11). Newcastle upon Tyne, UK: Cambridge Scholars.

Marsh, D., Maljers, A., \& Hartiala, A. (2001). Profiling European CLIL classrooms. Jyväskylä, Finland: University of Jyväskylä.

Mehisto, P., Marsh, D., \& Frigols, M. J. (2008). Uncovering CLIL: Content and language integrated learning in bilingual and multilingual education. Oxford, UK: Macmillan Education.

Meyer, O. (2010). Towards quality-CLIL: Successful planning and teaching strategies. Puls, 33, 11-29.

Ministerio de Educación, Cultura y Deporte. (2013). Ley Orgánica para la mejora de la calidad educativa. Retrieved from http://www.mecd.gob.es/educacion-mecd/areas-educacion/sistema-educativo/lomce.html

Navés, T., \& Muñoz, C. (1999). The implementation of CLIL in Spain. In D. Marsh \& G. Langé (Eds.). Implementing content and language integrated learning (pp. 145-158). Jyväskyla, Finland: ER-Paino/University of Jyväskyla Press.

Navés, T., \& Victori, M. (2010). CLIL in Catalonia: An overview of research studies. In D. Lasagabaster \& Y. Ruiz de Zarobe (eds.), CLIL in Spain: Implementation, results and teacher training (pp. 30-54). Newcastle upon Tyne, UK: Cambridge Scholars Press.

Navés, T. (2009). Effective content and language integrated learning (CLIL) programmes. In Y. Ruiz de Zarobe \& R. M. Jiménez Catalán (Eds.), Content and language integrated learning: Evidence from research in Europe (pp. 2240). Salisbury, UK: Short Run Press.

Pérez Álvarez, T., \& Aranzubía Benito, L. A. (2011). Sesiones tutoriales de matemáticas para alumnos de $4^{\circ}$ de ESO. Unpublished manuscript. Retrieved from http://www.larioja.org/upload/educarioja/html/docs/ premios_innovacion/2011/1_secundaria.pdf

Pérez-Vidal, C., \& Juan-Garau, M. (2010). To CLIL or not to CLIL? From bilingualism to multilingualism in Catalan/Spanish communities in Spain. In D. Lasagabaster \& Y. Ruiz de Zarobe (eds.), CLIL in Spain: Implementation, results and teacher training (pp. 115-38). Newcastle upon Tyne, UK: Cambridge Scholars Press.

Pons, E., \& Sorolla, N. (2009). Informe de la llengua catalana (2005-2007). Barcelona, Spain: Observatori de la Llengua Catalana.

San Isidro, X. (2010a). Análisis del modelo CLIL gallego. In C. Urmeneta, N. Evnitskaya, E. Moore, \& A. Patiño (Eds.), AICLE/CLIL/EMILE: Educació plurilingüe, Experiencias, research \& polítiques (pp. 327-36). Barcelona, Spain: Publicacions UAB.

San Isidro, X. (2010b). An insight into Galician CLIL: Provision and results. In D. Lasagabaster \& Y. Ruiz de Zarobe (eds.), CLIL in Spain: Implementation, results and teacher training (pp. 55-78). Newcastle upon Tyne, UK: Cambridge Scholars Press.

Sancho Guinda, C. (2013). Teacher Targets: A model for CLIL and ELF teacher education in polytechnic settings. Language Value, 1(5), 76-106. 
Wolff, D. (2007). CLIL: Bridging the gap between school and working life. In D. Marsh \&. D. Wolff (Eds.), Diverse contexts - covering goals: CLIL in Europe (pp. 15-25). Frankfurt, Germany: Peter Lang.

\section{BIODATA}

Francisco Guillamón-SUESTA graduated in English Studies (Linguistics and Literature) from Universitat Jaume I (Spain) in 2014, with an Extraordinary Academic Achievement Award. Previously, in 2013, he was also a graduate in Contemporary Studies from Coventry University (UK). He is currently studying a MA in English Language for International Trade and a MA in Teaching English as Foreign Language in Secondary Education. His research interests include Content and Language Integrated Learning (CLIL), English for Specific Purposes (ESP), multilingualism education and English language acquisition.

Maria Luisa Renau Renau is a full-time professor in the English Studies Department at Universitat Jaume I in Castellón, Spain. She has been teaching ESP for 14 years, mainly Computer Engineering courses. This fact has conducted her to do research in this field and more recently in the CLIL approach. Moreover, she has been an active member in the Cognitive Linguistics research group for four years. 